\title{
KOMUNIKASI ORGANISASI (ANALISISPENDEKATAN MIKRO) DALAM PELAKSANAAN REBOISASI PADA KESATUAN PENGELOLA HUTAN PRODUKSI (KPHP) MODEL PULAU LAUT DAN SEBUKU
}

\author{
Junet Usodo \\ E-mail: Junet.usodo@gmail.com \\ Ma'ruf Abdullah \\ Zain Noktah Aslie \\ Universitas Islam Kalimantan (UNISKA) MAB Banjarmasin
}

\begin{abstract}
Research is one of the objectives of to overcome problem in a organization on this research writer set some limits trouble is as follows: corrupt communication organization that occurs in units of unity of production forest management (KPHP) model sea island and sebuku, and approach micro to organizations especially approach among members organization in the implementation of the reforestation in units of unity of production forest management (KPHP) model sea island and sebuku especially on the implementation of reforestation. The results of the study found that communicate and coordinate with stakeholders to to institutional strengthening so that the implementation of reforestation possible consistent with the objectives of to be achieved.
\end{abstract}

Keywords: Organizational communications, Reboisation, forest production management 


\section{PENDAHULUAN}

Kata atau istilah komunikasi
(dari bahasa Inggris
“communication”),secara etimologis
atau menurut asal katanya adalah
dari bahasa Latin communicatus,
dan perkataan ini bersumber pada
kata communis Dalam kata
communis ini memiliki makna
'berbagi' atau 'menjadi milik
bersama' yaitu suatu usaha yang
memiliki tujuan untuk kebersamaan
atau kesamaan makna.

Komunikasi

secara

terminologis merujuk pada adanya proses penyampaian suatu pernyataan oleh seseorang kepada orang lain. Jadi dalam pengertian ini yang terlibat dalam komunikasi adalah manusia. Karena itu merujuk pada pengertian Ruben dan Steward(1998:16) mengenai komunikasi manusia yaitu:

Human communication is the process through which individuals -in relationships, group, organizations and societies-respond to and create messages to adapt to the environment and one another. Bahwa komunikasi manusia adalah proses yang melibatkan individu-individu dalam suatu hubungan, kelompok, organisasi dan masyarakat yang merespon dan menciptakan pesan untuk beradaptasi dengan lingkungan satu sama lain.

Aktifitas komunikasi dalam instansi pemerintah senantiasa disertai dengan adanya tujuan tujuan diantaranya adalah keberhasilan dalam tugas karyawan dalam keberhasilan pengelolaan instansi tersebut sesuai dengan visi dan misi yang telah di tetapkan, dengan metode komunikasi Organisasi.

Metode komunikasi organisasi adalah korelasi antara ilmu komunikasi dengan organisasi yang terfokus pada manusiamanusia yang terlibat dalam mencapai tujuan organisasi yang berfokus pada teknik, media, proses dan faktor-faktor yang menjadi penghambat proses komunikasi organisasi.

Kesatuan Pengelolaan Hutan Produksi (KPH) Model Pulau Laut 
dan Sebuku merupakan Unit pelaksana teknis Dinas Kehutanan Kabupaten Kotabaru dengan wilayah kerja meliputi Pulau laut dan Sebuku, ditetapkan berdasarkan Keputusan menteri Kehutanan Nomor : SK.78/MenhutII/2010 tanggal 10 februari 2010 tentang Penetapan kesatuan Pengelolaan hutan Lindung (KPHL) dan kesatuan Pengelolaan Hutan produksi (KPHP) provinsi Kalimantan selatan dan di tindaklanjuti dengan surat Keputusan Menteri Kehutanan Nomor SK.226/Menhut-II/2012 tanggal 04 mei 2012 Tentang Penetapan Wilayah Kesatuan Pengelolaan Hutan Produksi (KPHP) Model Pulau Laut dan sebuku (UnitIII) dengan Luas areal 103.368,29 На.

Krisis air bersih, kekeringan, kebakaran hutan dan lahan yang terjadi di Indonesia saat ini merupakan isu besar. Kemudian, terjadinya pemanasan global salah satu penyebabnya adalah degredasi hutan. Hutan di Indonesia merupakan paru-paru dunia. Salah satu cara untuk mengatasi isu dan fenomena alam di atas dengan dilakukannya reboisasi, dimana keberhasilan reboisasi sebagai tolak ukur tingkat keberhasilan pengelolaan hutan.

Sebagai unit organisasi, yang memiliki tujuan utama adalah keberhasilan dalam pengelolaan Hutan khususnya reboisasi sesuai dengan fungsi hutannya berdasrkan peraturan perundang undangan, dalam menyelenggarakan reboisasi dibentukalah susunan organisasi Kesatuan pengelola Hutan produksi, terdapat pelaksana kegiatan Reboisasi Komunikasi antar petugas pelaksana reboisasi dengan petugas lain serta dengan atasan langsung dalam hal ini adalah Kepala Kesatuan Pengelola Hutan Produksi (KKPH) haruslah berlangsung dengan baik dan terarah untuk mewujudkan keberhasilan. Seberapa jauh proses komunikasi organisasi dan pendekatan mikro denganPetugas pelaksana reboisasi 
untuk keberhasilan reboisasiperlu diketahui dengan adanya penelitian.

Penelitian adalah salah satu tujuan untuk mengatasi masalah yang ada dalam sebuah organisasi pada penelitian ini penulis menetapkan beberapa batasan masalah adalah sebagai berikut : masalah komunikasi organisasi yang terjadi pada Unit kesatuan pengelola Hutan Produksi (KPHP) Model Pulau Laut dan sebuku, dan pendekatan Mikro pada organisasi terutama pendekatan antar anggota organisasi dalam Pelaksanaan Reboisasi pada Unit kesatuan Pengelola hutan Produksi (KPHP) Model pulau laut dan sebuku khususnya pada pelaksanaan reboisasi.

\section{TINJAUAN PUSTAKA}

Fungsi komunikasi dan karateristiknya

Komunikasi adalah suatu proses atau kegiatan penyampaian pesan dari seseorang kepada orang lain untuk mencapai tujuan tertentu.
Komunikasi adalah prasyarat kehidupan manusia. Kehidupan manusia akan tampak hampa apabila tidak ada komunikasi. Karena tanpa komunikasi, interaksi antar manusia, baik secara perorangan, kelompok, ataupun organisasi tidak mungkin dapat terjadi. Dua orang dikatakan melakukan interaksi apabila masing-masing melakukan aksi dan reaksi. Aksi dan reaksi dilakukan manusia baik secara perorangan, kelompok, atau organisasi.

A. Komunikasi Organisasi

Komunikasi organisasi adalah pengiriman (sending) dan penerimaan (receiving) berbagai pesan organisasi di dalam kelompok di dalam kelompok formal maupun informal dari suatu organisasi. Bila organisasi semakin besar dan kompleks maka akan mengakibatkan semakin kompleks pula proses komunikasinya. Organisasi yang masih kecil, yang 


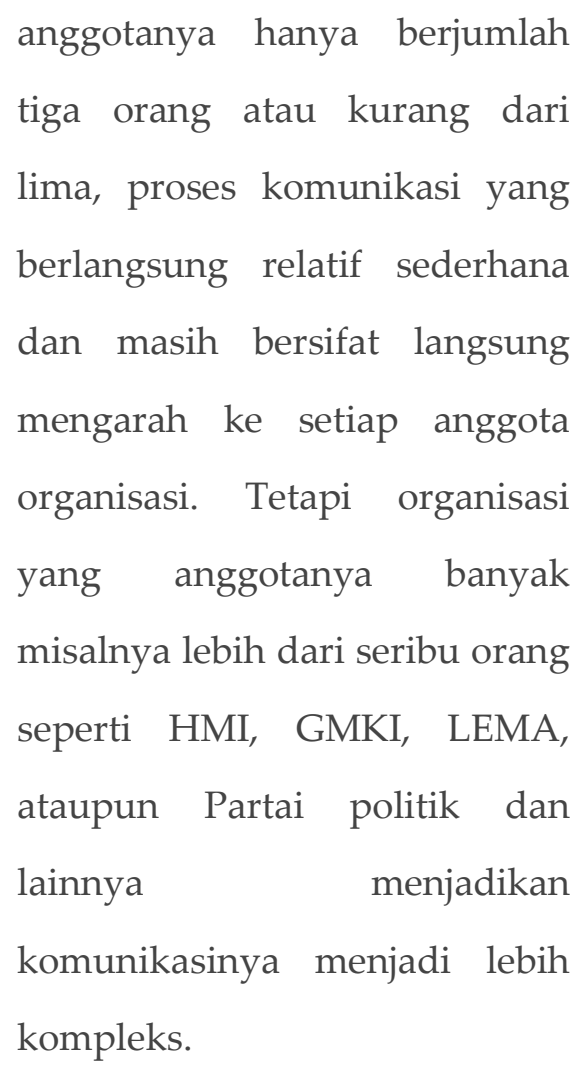

Komunikasi organisasi memiliki dua sifat yang tergantung oleh persetujuan yang dimiliki. Sifat dari komunikasi organisasi pertama ialah formal. Komunikasi organisasi formal adalah komunikasi yang disetujui oleh organisasi itu sendiri dan sifatnya beriorientasi kepentingan organisasi. Isinya berupa cara kerja di dalam organisasi, produktivitas dan berbagai pekerjaan yang harus dilakukan dalam organisasi.

\begin{abstract}
Seperti memo, pernyatan, kebijakan, surat surat resmi dan jumpa pers. Sifat organisasi yang kedua adalah komunikasi organisasi informal. Anggota organisai yang menggunakan komunikasi organisasi informal adalah komunikasi yang disetujui secara sosial. Arah komunikasi tersebut tidak secara langsung kepada organisasi melainkan kepada anggota individu atau anggota organisasi tersebut.
\end{abstract}

\section{METODOLOGI PENELITIAN}

Jenis penelitian deskriptif kualitatif dengan pendekatan fenomenologi, dengan menentukan kasus yang diteliti, terarah pada satu karakteristik, dilakukan pada satu sasaran atau lokasi atau subyek, yaitu hubungan pendekatan mikro komunikasi komunikasi organisasi dengan Keberhasilan reboisasi Pada Kesatuan pengelola Hutan Produksi (KPHP) Model Pulau Laut dan sebuku. 
Deskripsi meliputi, potret subyek, rekonstruksi dialog, catatan tentang berbagai peristiwa khusus. Pendeskripsian secara rinci dan mendalam mengenai potret kondisi tentang apa yang sebenarnya terjadi menurut apa adanya di lapangan.

Penelitian ini dilaksanakan di wilayah kesatuan pengelola hutan Produksi (KPHP) Model Pulau Laut dan Sebuku kabupaten Kotabaru.

Penetapan informan dilakukan dengan teknik sampling secara purposive sampling. Hal ini karena penetapan informan secara sengaja, karena pertimbangan tertentu.

Bertolak dari informasi diatas maka sebagai informan pada penelitian ini adalah :

a. Informan yang berada "di dalam" kesatuan organisasi Kesatuan pengelola Hutan Produksi (KPHP) Model Pulau Laut dan Sebuku yang ruang lingkup penugasannya berkaitan dengan Wilayah Pulau laut dan Sebuku

b. Informan yang berada "di luar" kesatuan organisai
Kesatuan Pengelola Hutan

produksi (KPHP) Model pulau Laut dan Sebuku tetapi aktivitasnya mempunyai keterkaitan.

c. Masing-masing kelompok informan di dalam dan yang di luar terdiri atas unsurunsur:

c.1. Masing-masing satu orang Top

Manager

c.2. Masing-masing dua orang yang

Middle Manager

c.3. Masing-masing tiga orang pada lowest Manager

d. Informan adalah orang-orang yang mampu dan mau memberikan informasi pada seluruh item-item pada kuesioner yang disiapkan.

A. Instrumen Penelitian

Instrumen ini mempunyai dua faktor, yaitu yang pertama adalah kualita instrumen penelitian dan faktor yang 
kedua adalah kualitas

pengumpulan data.

Dalam penelitian kualitatif, yang menjadi instrumen atau alat penelitian adalah peneliti itu sendiri. Di bantu dengan item-item pertanyaan untuk menggungkap informasi yang di perlukan sesuai dengan tujuan penelitian.

1. Kendala dan Hambatan dalam komunikasi organisasi

Dari hasil wawancara dengan berbagai Informan penulis selama melakukan penelitian pada unit Kesatuan pengelola hutan produksi Pulau laut dan sebuku ada beberapa hal yang menjadi hambatan hambatan dalam komunikasi organisasi yang seyogyanya di terapkan semua yang terlinbat dalam unit organisasi KPHP tersebut khususnya dalam Penyelenggaraan reboisasi , adapun hambatan hambatan yang dialami adalah sebagai berikut ; a. Kepala unit KPHP tidak mendapatkan informasi secara penuh dari bawahan khususnya dari penyuluh kehutanan sehingga disini tidak ada komunikasi dua arah antara Penyuluh Kehutanan Dengan Kepala unit KPHP. Penerimaan kendala dilapangan oleh Kepala Unit kurang terpenuhi secara maksimal, laporan pelaksana kegiatan pemahaman kelompok tani terhadap situasi dan kondisi, pemahaman kelompok terhadap perlakuan bibit, serta pemahaman kelompok terhadap hama dan penyakit tanaman. ( kendala Internal)

b. Penyuluh kehutanan dengan alasan kondisi jarak dan waktu intensitas komunikasi secara langsung dengan 


\begin{tabular}{|c|c|}
\hline kelompok kerja juga & pelaksanaan \\
\hline komunikasi & reboisasi, \\
\hline secara langsung ini sangat & hanya \\
\hline diperlaukan & komunikasi \\
\hline aplikasi dilapangan harus & koordinasi \\
\hline diterapkan & kelompok \\
\hline langsung tidak cukup & koordinasi \\
\hline informasi secara teori saja. & Kepala \\
\hline (kendala ekstern) & mendapatkan informasi \\
\hline c. Sebagai fasilitator Petugas & peningkatan \\
\hline Teknis Reboisasi Hanya & SDM masyarakat \\
\hline berkomunikasi & bidang kehutanan, akan \\
\hline tidak langsung dengan & berkaitan dengan mutu \\
\hline kelompok kerja ( melaluia & pelaksanaan \\
\hline Telepon) dimana hal ini & reboisasi. \\
\hline berpengaruh & Dari beberapa kendala \\
\hline terhadap & Komunikasi dalam organisasi \\
\hline lapangan sesungguhnya & Unit KPHP model Pulau laut \\
\hline dan akan sangat & sebuku \\
\hline menyulitkan koordinasi & memanfaatkan \\
\hline penyuluh & mikro dalam \\
\hline khususnya & Organisasi dimana pendekatan \\
\hline masalah yang lebih teknis & Mikro dalam sebuah organisasi \\
\hline menyangkut perlakuan & telah diuraikan dalam $\mathrm{BAB}$ \\
\hline tanaman kondisi lahan & sebelumnya bahawa sebagai \\
\hline dan kalender musim yang & tolak ukur keberhasilan dalam \\
\hline telah dibuat. & sebuah organisasi \\
\hline d. Tidak adanya koordinasi & diskription \\
\hline dengan Kepala Desa di & karyawan \\
\hline
\end{tabular}


pelaksanaan tugas dalam organisasi sehingga dalam Unit KPHP ini tida terjadi,Komunikasi untuk pemberian orientasi dan latihan, Komunikasi untuk melibatkan anggota kelompok dalam tugas kelompok. Komunikasi untuk menjaga iklim organisasi, Komunikasi dalam mensupervisi dan pengarahan pekerjaan, Komunikasi untuk mengetahui rasa kepuasan kerja dalam organisasi.

2. Hasil kerja Pelaksana Reboisasi pada unit KPHP Model Pulau Laut dan Sebuku.

Dari hasil kegiatan reboisasi tersebut ada beberapa hal yang bisa di kutip dari yang penulis dapatkan adalah sebagi berikut :

\section{a. Pelaksanaan Reboisasi dengan pola hutan Rakyat.} Bahwa kegiatan yang paling berhasil adalah reboisasi pada Hutan Rakyat, dikarenakan jenis bibit sesuai dengan kemauan masyarakat dan tanah adalah milik masyarakat sehingga terpelihara dengan baik oleh masyarakat itu sendiri. Adapun Pola yang digunakan dalam Pelaksanaan reboisasi Hutan Rakyat (HR) ada dua Pola yaitu pola pertama melalui Kebun Bibit Rakyat (KBR), pola yang digunakan ini dengan teknis satu Desa membuat kelompok tani yang disyahkan melalui kepala Desa serta kelompok tani membuat bibit sendiri dan menentukan jenis bibit sendiri, serta lokasi penanaman berada pada lahan milik masyarakat itu sendiri, hasil kemudian dimanfaatkan oleh kelompok tersebut, dan pola kedua dengan Pola pekarangan, tidak jauh beda dengan kebun Bibit Rakyat (KBR) yang membedakan pada Pola ini adalah bibit yang sudah di sediakan . pada pola kedua ini penulis berpendapat ada sisi negatif , dimana seperti yang penulis ungkapkan pada BAB sebelumnya bahwa pendekatan mikro dalam komunikasi sebuah 
organisasi, hal ini diperlukan salah satunya adalah untuk pemberian orientasi dan latihan pada sebuah kelompok organisasi. Pada kelompok tani pola pekarangan dengan menerima bibit langsung tanpa membuat sendiri memiliki sisi negatif, kelompok tani akhirnya tidak memiliki keterampilan, khususnya untuk pembuatan bibit tanaman yang akan mereka tanam. Selain itu Kurangnya dalam komunikasi untuk melibatkan anggota kelompok dalam tugas kelompoknya.Dari hal tersbut akhirnya rasa kepuasan kerja ada yang kurang.

Ada perbedaan yang nyata dengan yang dilakukan pada Pola Kebun Bibit Rakyat (KBR) walaupun hanya satu item yang dilakukan. Pada Pola Kebun Bibit Rakyat (KBR) Komunikasi organisasi lebih komplek pendekatan mikro dalam komunikasi pada kelompok Kebun ibit
Rakyat (KBR) seperti berjalannya dalam komunikasi untuk pemberian orientasi dan latihan pada anggota kelompok tersebut.

b. Pelaksanaan reboisasi Hutan lindung

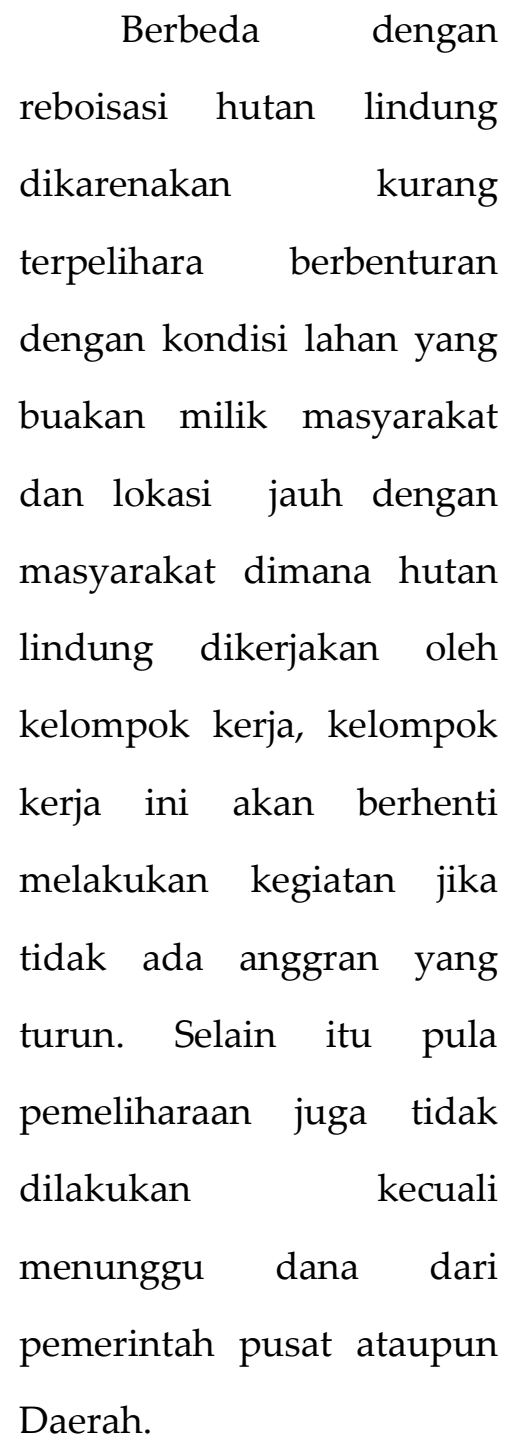

Daerah. 
Dalam Reboisasi

Hutan Lindung penanaman dilakukan oleh Kelompok Kerja bukan Kelompok Tani Masyarakat, dan kerjanya dilakukan dengan sistem upah, Jenis tanaman pun ditentukan pihak pemerintah dalam hal ini KPHP Model Pulau Laut dan Sebuku. Kalo dilihat seperti ini masyarakat kurang merasa memiliki dan memeliharapun akhirnya enggan jika tidak ada dana untuk pemeliharaan. Hal ini juga berkaitan dengan kepemilikan, tanah adalah milik Negara, Tanaman jiga sudah Usia Panen tidak boleh di tebang karena berada dikawasan hutan Lindung, dimana Hutan Lindung ini merupakan Hutan yang harus di jaga keberadaaannya karena berfungsi sebagai konservasi lahan untuk menjaga tatalingkungan dan siklus air. Kalau dilihat seperti ini penulis menilai tidak ada kepuasan kerja jika Kepala Kesatuan Pemangkuan Hutan Produksi, dalam menilai pelaksanaan Reboisasi hutan Lindung yang dilakukan oleh kelompok Kerja tersebut. Petugas teknis sebagai penanggung jawab menilai bahwa kelompok kerja untuk reboisasi hutan lindung tidak sesuai dengan job discription, karena merasa kurang ada kenyamanan dalam pelaksanaan pekerjaan. Dari beberapa hal tersebut di atas penulis mengungkapkan beberapa pendapat bahwa petugas pelaksana teknis reboisasi harus melakukan pendekatan secara teorotif dimana petugas teknis secara tidak langsung memaksa para anggota 
kelompok kerja reboisasi untuk sebisa mungkin melakukan penanaman di kawasan hutan lindung walaupun bibit dan hasil tidak bisa mereka miliki, tentunya dengan alasan seperti penjelasan diatas bahwa Hutan lindung memiliki fungsi ekologis yang sangat penting, walaupun tidak bisa dimanfaatkan secara langsung tapi pemanfaatannya bisa berkepannjangan.

Selain itu seperti yang dijelaskan pada BAB sebelumnya pada saat wawancara dengan kepala Dinas Kehutanan kawasan hutan lindung bisa memiliki nilai ekonomis apabila dijaga dengan baik. Nilai ekonomis tersebut didapat dari kawasan tersebut dijadikan kawasan ekowisata, dengan demikian bisamemperoleh hasil pendapatan daerah dari ekowisata, dan dengan adanya ekowisata masyarakat sekitar bisa terlibat dari segi pengelolaan tempat wisata. Tentunya perlu waktu dan proses

c. Reboisasi Hutan Lindung Melalui dana CSR.

Kegiatan reboisasi yang dilaksanakan oleh Perusahaan pemegang ijin Pemanfaatan Kawasan hutan biasa disebut dengan reklamasi. Pelaksanaannya dilaksanakan dengan Pola 1 ; 1 ( satu banding satu ) Seperti yang dilakukan oleh PT Karbon Mahakam perusahaan tersebut memiliki ijin pemakaian kawasan seluas 192 Ha maka perusahaan tersebut memiliki kewajiban melakukan reklamasi seluas 192 Ha. Pelaksanaan kegiatan ini baru tahap Pembuatan Rancangan Teknis reboisasi dimana berdasarkan rancangan 
teknis tersebut penanaman akan dilaksanakan pada tahun 2016,

$$
\text { Lokasi reklamasi }
$$

berada di dalam kawasan

Hutan lindung.

Pelaksanaan reklamasi ini

berbeda dengan

Pelaksanaan reboisasi

Hutan lindung yang

sebelumnya dilakukan oleh

Pemerintah. Dimana

Kelompok Kerja ditentukan

dengan pendekatan

wilayah, dimana mereka

yang berdekatan dengan

lokasi jenis tanaman pun

menyesuaikan dengan

tanaman unggulan lokal,

(Tanaman Buah dan karet)

jenis tanaman ini jika

sampai masa panen tidak

merusak tanaman karena

hanya mengambil buah

pada jenis buah buahan dan

getah pada jenis tanaman

karet. Dengan demikian

Konservasi lahan

pada kawasan tersebut tidak terganggu dan tata air tetap terjaga dengan baik.

Dalam pelaksanaan kegiatan ini penulis menyatakan bahwa komunikasi Organisasi berjalan dengan baik pelaksanaannya mendekati teori yang telah diungkapkan pada BAB sebelumnya. Seperti yang diungkapkan (robbin 2006:392) bahwa komunikasi organisasi menjalankan empat fungsi utama diantaranya

1) Pengendalian, untuk mengendalikan anggota kelompok dibentuklah kelompok berdasarkan pendekatan wilayah, penentuan jenis bibit di serahkan kepada kelompok jenis apa yang sesuai dengan tanaman unggulan setempat dan jika dipanen tidak merusak konservasi lahan dan tata kelola air 
sehingga lingkungan tetap terjaga.

2) Pengungkapan emosi bahwa disini masyarakat pada kelompok kerjanya tidak merasa kecewa dengan jerih payahnya menanam tanaman karena dikemudian hari bisa dimanfaatkan oleh mereke sendiri,

3) Motivasi, Masyarakat memiliki motivasi ganda disebabkan dengan lahan yang mereka kerjakan dekat dengan perumahan dan hasilnya akan bisa dimanfaatkan dengan ini kelompok kerja tidak merasa keberatan

4) Informasi dalam kegiatan ini jelas dikarenakan sebelum dilaksanakan kegiatan para anggota kelompok kerja melakukan diskusi dengan piha terkait untuk mendapatkan informasi-informasi penting seperti lokasi, jarak, dan pelaksanaanm metode dan jenis tanaman.

Perusahaan yang berada di kabupaten Kotabaru upaya yang dilakukan dalam pelaksanaan reboisasi melalui dana CSR selain dilakukan oleh perusahaan karbon mahakam, pada tahun 2009 s/d tahun 2011 telah dilakukan upaya reboisasi mangrove atau yang biasa dikenal dengan restorasi oleh PT. SILO.

3. Manfaat Pendekatan mikro dalam Unit KPHP Model Pulau Laut dan Sebuku.

Sudah kita ketahui bersama dan penulis sudah menguraikan pada $\mathrm{BAB}$ sebelumnya bahwa Pendekatan ini merupakan pendekatan yang memfokuskan kepada komunikasi dalam unit sub unit pada suatu organisasi. Dalam Unit Kesatuan Pengelola Hutan produksi Model Pulau Laut dan Sebuku Komunikasi yang diperlukan pada tingkat ini 


\begin{tabular}{|c|c|}
\hline komunikasi & utama adalah kelompok \\
\hline Petugas Pelaksana & Kerja pelaksana reboisasi \\
\hline Kelompok & dalam melakukan kegiatan, \\
\hline Pelaksana & ini diperlukan \\
\hline Kehutanan & komunikasi. \\
\hline Kepala & Berawal dari \\
\hline sendiri.Komunikasi & orientasi yang merupakan \\
\hline diperlukan dalam tingkat ini & proses yang terus menerus \\
\hline adalah komunikasi & menghendaki \\
\hline anggota kelompok tersebut : & oranglain apa yang sedang \\
\hline 1. Bahwa komunikasi untuk & berlangsung dalam sebuah \\
\hline memberikan orientasi dan & organisasi, secara \\
\hline latihan dalam sebuah & langsung sudah terjadi \\
\hline organisasi Unit KPHP & pada kelompok tani Kebun \\
\hline Model pulau Laut dan & Bibit Rakyat \\
\hline sebuku, komunitasnya & Organisasi pada kelompok \\
\hline berasal dari berbagai & ini melakukan \\
\hline disiplin ilmu tertentu dalam & orientasi \\
\hline mewujudkan sebuah visi & dengan membuat \\
\hline misi sebuah organisasi & sendiri, diawali dengan \\
\hline dalam hal ini adalah & pembuat bedengan yang \\
\hline tujuannya untuk mencapai & notabene merak \\
\hline keberhasilan pelaksanaan & umum tidak mengetahui \\
\hline reboisasi maka dibutuhkan & teknis pembuatan bibit \\
\hline dan diperlukan kehadiran & berdasrkan \\
\hline sebuah orientasi dan & pengalaman \\
\hline training kepada Petugas & melakukan \\
\hline teknis Reboisasi, Penyuluh & pelatihan \\
\hline Kehutanan dan paling & langsung, \\
\hline
\end{tabular}


berkomunikasi dengan

penyuluh maupun petugas

teknis reboisasi. Walaupun

demikian

untuk

peningkatan kualitas

Sumber daya Manusia

seperti yang dijelaskan

pada wawancara dengan

kepala Dinas Kehutanan,

bahwasannya SDM

kelompok tani perlu

ditingkatkan dengan

pelatihan kelompok seperti,

pelatihan manajemen

kelompok Tani, Penguatan

Kelembagaan Kelompok

Tani, sehingga kedepannya

kelompok bisa mandiri

serta bisa mengadakan

kegiatan tanpa adanya

proyek pemerintah.

2. Keterlibatan anggota untuk menjaga kelancaran

organisasi maka

diperlukanlah anggota

dalam unit masing masing

tetap focus padatugas

bidang masing masing, hal

ini sesuai dengan keahlian masing masing. Dan

keinginan anggota

organisasi. Dalam menjaga

hal ini tidak lepas dari yang

namanya komunikasi dan

koordinasi dengan

pimpinan terkait demi

menjaga dan memotivasi

agar anggotanya bekerja

sesuai dengan unit yang

telah ditentukan sebagai

berikut ;

1) Sesuai dengan struktur organisasi KPHP Model

Pulau Laut dan sebuku.

Bekerja sesuai dengan

job discription.

2) Kegiatan reboisasi Hutan

Rakyat dengan Pola

Kebun Bibit Rakyat (

KBR) Kelompok tani

bekerja sesuai dengan

tugas yang diberikan

oleh ketua kelompok

mereka bertugas masing

masing sesuai dengan

jenis pekerjaan yang

telah ditetapkan. 
3. Penentuan iklim organisasi, iklim sebuah organisasi sangat bergantung kepada tingkah laku pemimpin tingkah laku pekerja maupun anggota atau organisasi tetapi pada dasarnya iklim organisasi ditentukan oleh bagaimana komunikasi antara pemimpin dan bawahannya, jika kita ambil contoh jika pimpinan tidak melakukan komunikasi dengan baik kepada bawahannya ini akan menjadikan bawahannya malas dan tidak ada semangat bekerja demi tujuan sebuah organisasi. Dapat kita lihat pada uraian BAB sebelumnya bahwasannya yang dilakukan Kepala KPHP sebagai pemimpin organisasi sebagai sebab tidak adanya laporan dari penyuluh kehutanan berkaitan pekerjaan dilapangan maka Kepala KPHP seharusnya mengambil tindakan dengan selalu memberikan pengawasan, kepada penyuluh, petugas teknis maupun kelompok tani pelaksana reboisasi, penulis berpendapat pada saat bersama sama turun kelapangan seharusnya Kepala unit KPHP mengajak berdiskusi langsung dengan Kelompok kerja apa kendala yang terjadi dilapangan, dengan demikian secara langsung dapat pemikiran bagaimana cara mengatasi persolan tersebut, tentunya di diskusikan dan diselaesaikan secara bersama sama dengan kelompok Kerja, Penyuluh, Petugas Teknis, dan bila perlu dengan kepala Desa setempat yang lebih tahu kondisi, dan karakteristik lokasi Desa tersebut. 
Sehingga permaslahan lebih cepat diselesaikan dan iklim organisasi terlihat terjaga

4. Semua tugas dan pekerjaan dalam lingkup organisasi sangat perlu dilaksanakan pengawasan serta diarahkan sesuai dengan kriteria yang berlaku, ini dilakukan oleh seorang pimpinan dan bawahan. Seorang supervisor bertanggung jawab terhadap orang yang dibawah.dan bertanggung jawab pula dalam membantu pekerjaan bawahannya dalam mewujudkan pekerjaan. Dalam Pelaksanaan reboisasi jika tidak dilakukan pengawasan secara intens maka pelaksanaan dilapangan akan terlihat gagal. Kepala Unit KPHP harus melakukan pengawasan terhadap Komunikasi dan kordinasi

dengan

stakeholder

Koordinasi

dan

komunikasi merupakan hal yang sangat penting dan harus ada dalam suatu organisasi, karena koordinasi dan komunikasi merupakan pendukung tercapainya tujuan yang ada dalam suatu organisasi. Komunikasi dan koordinasi di sini berhubungan dengan kepemimpinan dari suatu organisasi, baik organisasi dalam pendidikan maupun di luar pendidikan.

Dengan koordinasi dan komunikasi yang baik dalam suatu organisasi, maka akan menghasilkan hasil yang baik pula, serta lebih maksimal dalam mencapai tujuan. Oleh karena itu dibutuhkan kerjasama yang baik antara Kepala unit KPHP Model Pulau Laut dan sebuku dengan bawahannya serta para stkeholder, ataupun sesama anggota yang ada 


dalam suatu organisasi.
Intinya adalah harus ada
kerjasama yang baik antar
semua komponen yang ada
dalam suatu organisasi.

Komunikasi dan Koordinasi yang dilakukan seperti melakukan konsultasi publik dengan para stake holder yang berada di wilayah kelola, dengan demikian ppara stake holder memberikan dukungan penuh terhadap pelaksanaan reboisasi. sehingga terjadi kesamaan persepsi untuk mensukseskan keberhasilan reboisasi di wilayah tersebut.

Stakeholder senantiasa memberikan tanggapan yang positif apabila selalu dilibatkan dalam pelaksanaan kegiatan reboisasi. Bahkan ada beberpa yang menilai bahwasannya kegiatan yang dilakukan kehutanan tidak ada nilai manfaatnya, mereka berpendapat bahwa terlalu panjang untuk menunggu hasil di bidang kehutanan yang akan di butuhkan oleh masyarakat adalah saat sekarang. Oleh karena itu beberpa pendapat yang demikian ini perlu diluruskan dengan jalan seperti penulis utarakan diatas. Dengan demikian akan muncul satu kesepahaman. Penulis berpendapat bahwa selama ini yang ada adalah para stakeholder kadang mendengar hanya dari sebelah pihak dan tidak dicerna dengan secara bijaksana, Seperti yang diungakapkan oleh beberapa LSM sebelum penulis melakukan penelitian, ada beberapa lembaga Swadaya yang mengatakan bahwa Kegiatan yang dilakukan oleh kehutanan tidak memiliki manfaat bagi masyarakat.

Ungkapan demikian penulis berpendapat bahwa mereka berani berbicara seperti ini dikarenakan tidak pernah dilibatkannya dalam urusan kehutanan lebih lebih dalam kegiatan proyek semacam reboisasi. Dengan demikian jika kita ajak duduk bersama berdiskusi tentang pelaksanaan kegiatan reboisasi saling bekerja sama dan ber koordinasi, tentunya 
mereka akan beranggapan positif terhadap pelaksanaan kegiatan yang dilaksanakan oleh kehutanan.

Kepala unit KPHP tentunya sebagai insan kehutanan harus melakukan koordinasi dengan pihak pihak terkait dalam pelaksanaan reboisasi kedepannya. Karena pasca kebakaran kawasan pemangkuan Hutan wilayah KPHP pulau laut dan sebuku banyak yang terbakar dan tentunya harus segera dilakukan reboisasi.

Semua program kerja dapat terselesaikan dengan adanya komunikasi dan koordinasi, maka perlu bantuan orang lain. karena kita tahu bahwa yang dibutuhkan organisasi ini adalah SUPERTIM bukan SUPERMAN. Kalau yang bekerja hanya sendirian tanpa meminta bantuan takkan ada yang mampu melaksanakannya. Satu tusuk lidi saja tidak mampu membersihkan tapi dengan kumpulan banyak lidi mampu membersihkan kotoran yang ada. Itulah organisasi yang baik satu sama lain saling berkomunikasi dan koordinasi dalam bekerja.

\section{Kesimpulan}

Dari Hasil Penelitan dan Pembahasan di atas penulis dapat menarik kesimpulan sebagai berikut

1. Komunikasi Organisasi dalam Unit Kesatuan Pengelola Hutan Produksi Model Pulau Laut dan sebuku tidak terjalin dengan baik dikarenakan beberapa faktor internal dan eksternal.

2. Terjadi kendala komunikasi Organisasi Pelaksanaan reboisasi pada unit Kesatuan Pengelolaan Hutan produksi Model Pulau Laut dan sebuku adanya faktor lingkungan ( lokasi dan waktu Pelaksanaan reboisasi)

3. Hasil kerja reboisasi pada Unit Kesatuan pengelola hutan Produksi Model Pulau Laut dan sebuku Belum optimal dikarenakan Urang komunikasi antara Kelompok 
kerja, Petugas Teknis kedepannya berjalan dengan baik, Pelaksana reboisasi dan kepala diantaranya sebagai berikut :

unit KPHP

1. Menggunakan Komunikasi

4. Pendekatan Mikro tidak dimanfaatakan dengan baik terhadap kelompok kerja dan anggoata Unit pelaksana teknis Kesatuan pengelola Hutan Produksi Model pulau Laut dan sebuku, sehingga tidak terjadi kenyamanan kerja Personil pada Unti Organisasi tersebut.

5. Peningkatan komunikasi dan koordinasi dengan stake Holder dengan tujuan untuk penguatan kelembagaan agar pelaksanaan reboisasi kedepannya berjalan dengan baik dan terarah.

Saran

Dari hasil penelitian dan pembahasan yang telah disimpulkan penulis mengajukan beberapa saran guna ditindaklanjuti baik oleh Kepala unit ataupun petugas Pelaksana reboisasi agar pelaksanaan kegiatan reboisasi

\section{DAFTAR PUSTAKA}

Muhammad Arni 2004. Komunikasi Organisasi Jakarta Bumi Aksara

Khosahrial Romli 2011. Komunikasi Organisasi Lengkap, Jakarta grasindo 
Akdon. 2006. Strategic Managemen for Educational Management. Bandung: Alfabeta.

Berelson, Bernard and Garry A Stainer. 1979. Communication and Transmission of Information.Cambridge

University Press.

Massachussetts. Third Edition.

Berlo, David K.1960. The Processof Communication.An

Introduction To Theory and Practice. Holt, Rinehart and Winston. New York -Toronto London. The First Edition Creswell, John W. 1998. Qualitative Inquiry and Research Design. Sage Publication, Inc, California. Gamble, Michael W and Teri Kwal Gamble. 1986. Introduction of Massa Communication. McGraw Hill Book Company. New York. Third Edition.

Grounlund, Norman E. 1971. Reading In Mesurement and Evaluation. The Macmillan Company. Colier-Macmillan
Limited. London. Third Printing.

Guba, E.G. and Y.B. Lincoln.1990. Efective Evaluation. Joossey Baas Publication. San Franscisco.The 5 th Edition.

J, Winardi. 2001, Motivasi dan Pemotivasian dalam Manajemen, Jakarta, Raja Grafindo Persada.

Koentjaraningrat. 1985.

"Pengamatan Terlibat oleh Seorang Peneliti Pribumi dan Asing:Masalah Masuk Ke Dalam Dan Ke Luar dari Kebudayaan" dalam Kontjaraningrat \& Donald K. Emmerson. Aspek Manusia Dalam Penelitian Masyarakat, PT Gramedia, Jakarta.

Kirk, Jerome \& Marc L. Miller.1986. Rehability and Validity in Qualitative Research, Sage Publication. Beverly Hills.

Lexy J Moleong. 1997. Metode Penelitian Kualitatif, PT Remaja Rosdakarya, Bandung. 
Mulyana,Deddy.2011.Metodelogi

Penelitian Kualitatif

Paradigma Baru Ilmu

Komunikasi dan Sosial

Lainnya. Bandung : Remaja

rosda karya.

Mulyana, Deddy.2007. Ilmu

Komunikasi

Suatu

Pengantar.

Bandung:

PT.Remaja Rosdakarya.

Neuman,W.Laurence. 2004. Social

Research

Method,
Qualitative and

Qualitative Approach. The

Mcmillan Publishing, Co.

NewYork. Second Edition

Pawito. 2007, Penelitiun

Komunikasi Kualitatif, PT LKiS

Pelangi Aksara Yogyakart 